\title{
Loop-Mediated Isothermal Amplification (LAMP): Comparative Advances over Conventional PCR and Other Molecular Techniques
}

\author{
Yahaya Hassan ${ }^{1,2}$ and Leslie Thian Lung Than ${ }^{2^{\star}}$ \\ ${ }^{1}$ Department of Medical Laboratory Science, Faculty of Allied Health Sciences, Bayero University, \\ Kano, Nigeria. \\ ${ }^{2}$ Department of Medical Microbiology and Parasitology, Faculty of Medicine and Health Sciences, \\ University Putra Malaysia, 43400, Selangor, Malaysia.
}

Authors' contributions

This work was carried out in collaboration between both authors. Both authors read and approved the final manuscript.

Article Information

DOI: $10.9734 / A R R B / 2020 / v 35 i 830257$

Editor(s):

(1) Dr. Paola Angelini, University of Perugia, Italy.

Reviewers:

(1) Himanshu Dehra, India.

(2) Salem Aboglila, Azzaytuna University, Libya. Complete Peer review History: http://www.sdiarticle4.com/review-history/59713

Review Article

Received 24 May 2020

Accepted 30 July 2020

Published 08 August 2020

\begin{abstract}
Gene amplification technology is essential in the fields of diagnostic medicine. The polymerase chain reaction (PCR) is central in the molecular studies and provides ways for diagnostic advancement in the areas. However, the requirement for thermal cycler in a dedicated facility for amplification of target genes in the PCR technique has been a bottleneck to many researchers. The limitations associated with PCR include cost implication, strict expertise necessity and relatively higher turn-around time. The emergence of loop-mediated isothermal amplification (LAMP) in the last two decades assists in bridging the undesirable gaps. This review aims to highlight the natural advantages of the LAMP technique over the existing conventional PCR and other isothermal molecular techniques. Available published articles on LAMP techniques reviewed, listed many outstanding advances of the method in comparison to traditional PCR technique. The mentioned advantages include simplicity, affordability, naked-eye result detection and many more. That made LAMP becomes a rapidly accepted method in the field of molecular diagnosis. Other essential features of LAMP in comparison with other emerging nucleic acid amplification techniques were
\end{abstract}


adequately explained and presented in tabular form for research and quick reference purposes. Though LAMP has some few limitations, its advantages outweigh its flaws by filling the gap in the field of molecular biology diagnostics.

Keywords: Advantages; gaps LAMP; nucleic acid; PCR.

\section{INTRODUCTION}

Accuracy in molecular diagnostic studies on diseases is necessary for effective treatment outcome and control [1]. In recent years, nucleic acid-based techniques have increased the speed sensitivity and specificity of the diagnosis of infections [2]. The requirement for thermal cycler machine and a dedicated facility for amplification of target genes using PCR technique has been a bottleneck to many researchers. The limitations involved the cost burden, strict expertise and relatively higher turn-around time (TAT) [3]. Despite many excellent improvements associated with these techniques, mostly attributed to PCR, there exist some limitations not adequately addressed, as reported by [4]. The emergence of LAMP technique introduced first in the early 2000s has helped to fill those gaps. It is an excellent isothermal rapid diagnostic technique used for detection and identification of infectious agents [5-7] food safety assessment $[8,9]$, a study on genetic disorders and genetic traits, single nucleotide polymorphism (SNP) study [10], and many other research applications [11].

The technique is simple and it facilitates the detection through rapid amplification of a few target DNA into billions of copies at a constant temperature. The temperature is within the range of $60-65^{\circ} \mathrm{C}$ in the presence of $4-6$ primers specially designed to target $6-8$ specific regions on the target DNA. It works on the auto cycling displacement activity of Bacillus stearothermophilus (Bst) large fragment on double-stranded target DNA. The amplification cycles occur within one hour and is a cheap alternative approach for detection of diseases [12]. It has the advantage of having many modes of amplicons detection methods after the LAMP reaction. The first method used for detection was naked eye monitoring using DNA intercalating agents such as SYBR green I or ethidium bromide (EtBr) [13]. Recently, many methods of detection to improve sensitivity have emerged. These include gel electrophoresis, real-time turbidimeter, real-time fluorescence and electrochemical biosensors [12]. Its relevance in the molecular field lies on its non-requirement of thermal cycler machine used in PCR for amplification. It requires only a heat block or a water bath to achieve amplification. Its simplicity, rapidity and non-machine dependence are the significant attributes that make it potentially applied in point-of-care-testing (POCT). It helps in early diagnosis of diseases, offer therapeutic measures and preventative actions when an outbreak of disease is anticipated, particularly in low-resource settings. The review aimed to elucidate the advantages of LAMP over PCR and other molecular techniques.

\section{SUPERIOR ATTRIBUTES OF THE LAMP ASSAY}

There are many advantages of LAMP assay over other nucleic acid-based tests. These are mostly associated with standout qualities like simplicity, low TAT, precision, high yield of amplicon and less costly as explained as separate benefits below. According to the World Health Organization (WHO) definition, POCT must conform with a set criterion, put together in an acronym "ASSURED". These are affordable, sensitive, specific, user-friendly, rapid/robust, equipment-free or minimal and deliverable to the concerned who are in dare need [14].

\subsection{Visual Detection of Results}

LAMP assay can be detected using visual detection with the naked eye as a result of the accumulation of turbid white magnesium pyrophosphate as a by-product of DNA amplification. LAMP products visualised by direct fluorescence using fluorescence dyes such as ethidium bromide (EtBr), SYBR green, Quant-iT picoGreen, GeneFinder, polyethylenimine, or Evergreen $[12,15]$. The dyes are applicable for qualitative and quantitative measurement. The hydroxy naphthol blue (HNB) [16] and calcein $[12,17]$ are indirect colourimetric indicators used for one-step reaction by adding them during LAMP mixture preparation. Calcein dye also applicable in real-time monitoring of LAMP reaction [17]. In limited-resource settings, naked eye monitoring of LAMP result will be paramount in speeding clinical judgment and reducing mortality rate to common and treatable infections. 

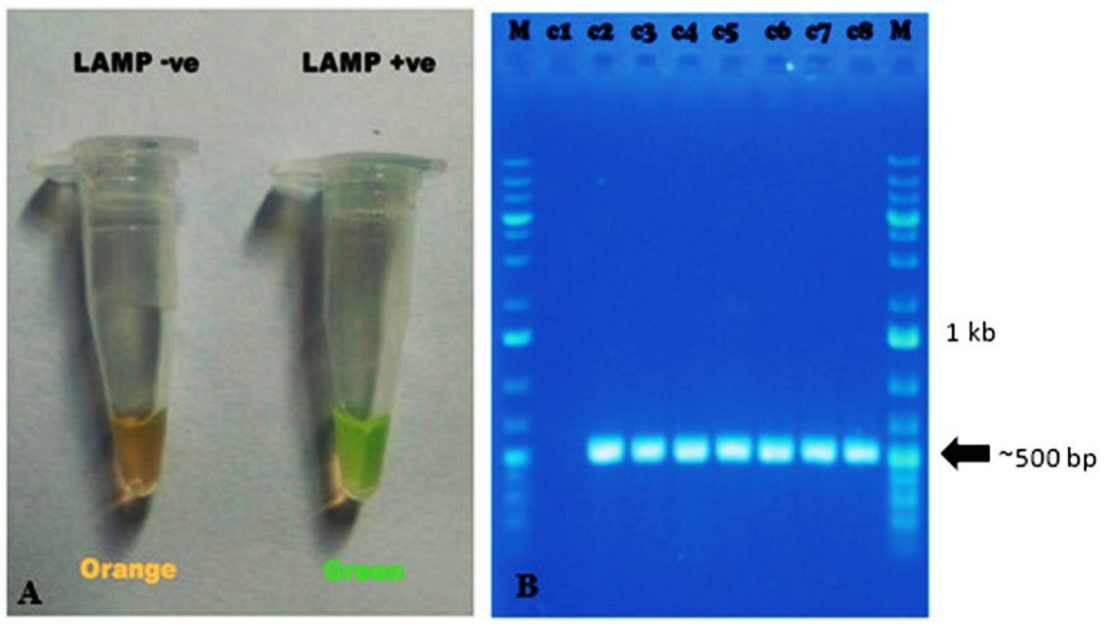

Fig. 1. A: LAMP assay visual detection results using calcein dye indicator; orange indicates negative, while green indicates positive to the target gene. B: Gel electrophoresis for detection of PCR results

Since quantitative detection is complicated and needs further approach, the naked eye could easily indicate whether a LAMP reaction is positive or negative. Based on the developed turbidity [18] or change of colour of the dye to the final positive colour after the reaction [16] as shown in Fig. 1. Here, the colour changed from orange to green using calcein dye. In contrast to traditional PCR that relies only on gel electrophoresis for DNA analysis. The UV transilluminator necessary need to view and identify the target DNA.

\subsection{The High Sensitivity of LAMP Assay}

The sensitivity of the LAMP is mainly dependent on the primer set and its low ability to amplify non-template DNA. Primers design to produce an amplicon size of approximately $<300$ bp allows for excellent sensitivity and increases the reaction speed [19]. Tian and coworkers [20] also reported the use of high concentrations of inner primers (FIP and BIP, 1.6 $\mu \mathrm{M}$ each) accelerates LAMP reaction. It thus results in high yield of amplicons [20]. The sensitivity is measured based on either the detection of low copy number or a high dilution of genomic DNA of the target template or detection limit from the spiked sample in comparison to the standard gold method. LAMP assay found to be very sensitive in detecting the target template [21]. Typical of LAMP assay is the dynamic range of amplicon concentration within $10^{4}-10^{8}$ copies. It can detect as low as $1-1000$ copies of the template, and that shows its robustness in terms of sensitivity as reported by Wang et al. [15], with the limit of detection of 10 copies $/ \mu \mathrm{L}$ of target DNA. Notomi et al. [11] also reported a detection limit of 6 copies/ $\mu \mathrm{L}$ of hepatitis $\mathrm{B}$ virus (HBV) DNA template. The findings supported other results, including Chen et al. [22] that reported high sensitivity as low as 3 copies/ $\mu \mathrm{L}$ using multiplex microfluidic LAMP assay.

The detection limit, when compared to PCR sensitivity, as published by Adao and Rivera [5], was 0.1 cells $/ \mathrm{ml}$ which is much lower than 100 cells/mL in PCR for detection of Trichomonas vaginalis. It further lends more credence to LAMP over PCR technique in terms of sensitivity. Concordant findings of Seki et al. [23] reported a low detection limit of 10 cells/reaction of pneumococci from purified DNA. Spiked CSF sample within $30 \mathrm{~min}$ with 100 -fold sensitivity over conventional PCR detected $10^{4}$ cells/reaction. Some sensitivity findings were reported in the colony-forming unit per millilitre $(\mathrm{CFU} / \mathrm{mL})$ as reported by Park et al. [24] that indicated $2 \mathrm{CFU} / 200 \mu \mathrm{L}$. Wang et al. [25] also reported a detection limit of $4.2 \times 10^{2} \mathrm{CFU} / \mathrm{mL}$ of $V$. parahaemolyticus DNA from the spiked oyster homogenate. The above findings show higher sensitivity benefits of LAMP over conventional PCR.

\subsection{The High Specificity of the LAMP Assay}

The specificity testing of LAMP assay usually tested using genomic DNA of closely related organisms. Its preference over conventional PCR is due to the specificity of the primers targeting 
template, as shown in Fig. 2 [26]. According to the findings by Kasahara et al. [27], the specificity of primers sets for conventional LAMP assays tested with $10 \mathrm{ng}$ of the purified DNA of the 20 strains of target species and 33 related species from 10 genera. The primer sets detected all the 20 strains of interest successfully without amplification of non-target species, within $30 \mathrm{~min}$ of LAMP reaction. Despite the higher number of primers for LAMP assay, LAMP multiplex assay is practically applicable with robust specificity. Mandappa and Joglekar [28] reported high specificity of LAMP their primer sets on the extracted DNA of four different genes of Bacillus cereus (hemolysin-A (hblA), Enterotoxin-T (bceT), Enterotoxin-FM (entFM/cwpFM) and Cytotoxin-K (CytK) and the primers selectively targeted diarrhoeal genes. No cross-reactivity noticed with other organisms. The relatively higher specificity is one of the significant advantageous attributes of LAMP when compared to other nucleic acid amplification-based techniques. Table 1 below indicates findings from different authors that affirm LAMP as a method that has high yield ability in comparison to PCR technique.

\subsection{Target Template Amplification at a Constant Temperature}

Loop-mediated isothermal amplification technique has the capability of revolutionising the molecular-based diagnostic approach to infections. It is through reducing the dependence of sophisticated, expensive, and facility-domiciled instruments resulting in low running cost and short TAT. Moreover, LAMP anticipated being a low cost molecular diagnostic tool, particularly in limited-resource environments [29]. The LAMP test materials easily transported because of small size with minimal facilities requirement, maintenance and do not require highly skilled staff to run it [30]. The LAMP assay has superiority based on its ability to operate at a constant temperature.

Contrary to other molecular-based amplification techniques such as PCR that requires thermal cycler, set at alternating temperature cycles and necessary steps. The primers are designed and synthesised with an optimum temperature range between $60-65^{\circ} \mathrm{C}$, which is also optimum for Bst enzyme displacement and amplification activities [13,24]. The main advantage of LAMP techniques in POCT lies on its reagents' ability to remain stable at room temperature during storage. According to Thekisoe et al. [31] and Notomi et al. [32], newly developed LAMP reagents can be stored efficiently both at $25^{\circ} \mathrm{C}$ and $37^{\circ} \mathrm{C}$. Thus, supported the use of LAMP in the field as well as in resource-limited settings where there is no stable power supply for refrigeration of reagents.
PCR amplification steps

Denaturation $\quad \Rightarrow \begin{aligned} & \text { Annealing } \\ & 92^{\circ} \mathrm{C}-95^{\circ} \mathrm{C}\end{aligned} \quad \begin{aligned} & \text { Extension } \\ & 72^{\circ} \mathrm{C}-60^{\circ} \mathrm{C}\end{aligned} \quad-75^{\circ} \mathrm{C}$
LAMP amplification Constant temperature $60^{\circ} \mathrm{C}-65^{\circ} \mathrm{C}$

\subsection{Various Methods of Detection}

Loop-mediated isothermal amplification, unlike other nucleic acid-based techniques, could monitor the amplification reaction of template in diverse approaches. It solely depends on the availability of resources in the laboratory and the required standards of sensitivity and specificity used. The search for an efficient method of detection lies in need of improving sensitivity, specificity, the stability of the amplified LAMP amplicons, simplicity and POCT [12]. For example, as shown in Fig. 2, in a resourcelimited setting, naked-eye monitoring is enough for detection of template of interest. When using hydroxy naphthol blue (HNB), the colour changes from violet to sky blue if the reaction turns positive. When the result turns out negative, the colour remains violet. The LAMP assay progression monitored using calcein dye to give a change of tone from orange (negative) to green (positive). Thus, it shows its simplicity and cost advantage compared to PCR, which uses only gel electrophoresis for target identification. Also, the additional cost of gel electrophoresis machine and staining reagents is another disadvantage. Of note, LAMP genetic analysis depends not only on the efficacy of template amplification but based on the practical method of reaction monitoring since there are many methods of choice $[12,33]$. 

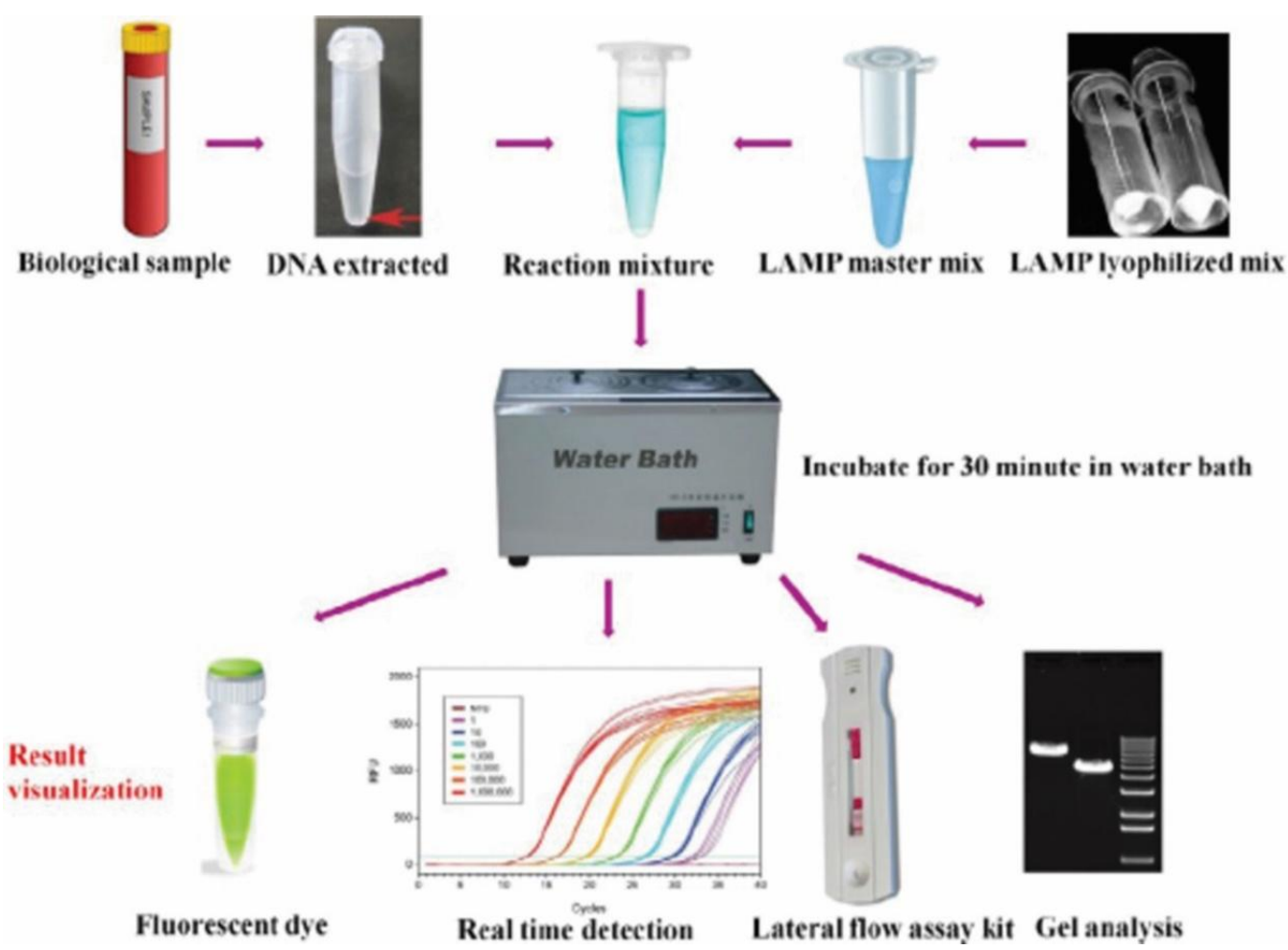

Fig. 2. Examples of various methods of detection and advantages at a glance of the LAMP technique. Image adapted from Ranjan [34]

\subsection{Low Susceptibility to Reaction Inhibitors}

The LAMP excellent property of makes it less sensitive to reaction inhibitors such as $\mathrm{Ca}^{2+}[35]$, fat, casein [36], proteinases [37] and urine helps it adopted by many researchers in the field of molecular diagnostic. The substances are known to affect PCR based reactions adversely [24]. The technique uses a powder in the reaction components, which removes all inhibitors of the reaction and makes DNA free in the solution [38]. Reports indicated that the sensitivity of LAMP is not affected by the presence of non-target DNA in the reaction tube $[39,40]$. Supported by Kiddle et al. [41] that LAMP is tolerant of inhibitory materials known to inhibit PCR reactions. These include blood, serum, and food ingredients, suggesting omission of template purification in LAMP protocol and therefore, lowers time to result in analysis.

\subsection{Direct Sample Preparation without DNA Extraction}

The traditional methods of detecting infectious agents are culture, microscopy and histopathology and these methods have their disadvantages in terms of sensitivity and specificity. Moreover, they are known for being laborious and time-consuming [42]. Hence, it is necessary to emphasise the development of more sensitive molecular techniques. These are based on nucleic acid pathogenic agents and not based on its growth on microbiological culture media. Such methods include PCR and hybridisation, but they are still laborious and expensive [43]. These limitations led to the search for novel approaches, and one of them is the LAMP technique. This technique can directly process sample in the field without extraction of the target nucleic acid template, and that increases its rapidity and subsequently reduces TAT. It is relatively more superior in terms of sensitivity and specificity with comparably low susceptibility to reaction inhibitors that generally inhibit PCR and its cohorts as reported by Niessen et al. [44]. The ability of LAMP technique to exhibit less sensitivity to reaction inhibitors such as a urine, serum, plasma, and culture medium present in biological samples is critical, particularly in the field of POCT. Therefore, it indicates it robustness, reduces cost and time-to-result, unlike PCR that 
can efficiently be inhibited by these substances [23].

\subsection{High Yield of Bst DNA Polymerase}

The success of sound amplification of target template and reaction sensitivity lies in the type of DNA polymerase used in the reaction. The Bst DNA polymerase enzyme, used in LAMP assay is a large fragment engineered polymerase derived from Bacillus stearothermophilus with improved properties of rapid amplification, 5'-3' exonuclease activity and template strand displacement. The Bst enzyme was also known to have the tolerance to reaction inhibitors, thermostability. It incorporates deoxyuridine triphosphate (dUTP) for DNA sequencing and cloning applications. Furthermore, these properties occur both in Bst 2.0 and Bst 3.0 [45]. The Bst also shows significant reverse transcriptase activity up to $72^{\circ} \mathrm{C}$ used for RTLAMP reaction as occurred only in Bst 3.0 $[46,47]$. The significant difference between $B s t$ DNA polymerase and the Taq polymerase used in PCR reactions is the intense strand displacement activity of the former. At the same time, the latter has weaker or no displacement activity and therefore not fit for LAMP assay as no significant amplicon would be produced [48]. Niessen et al. [44] relate the high molecular weight of DNA built through the excellent activity of Bst. Besides, Sahoo et al. [34] reported high amplification efficiency of Bst, amplifying DNA $10^{9}-10^{10}$ times within one hour.

\subsection{Formation of Loop Amplicons after LAMP Reaction}

LAMP amplification reaction exists in two steps, namely: non-cyclic and cyclic phase. The endproduct of the non-cyclic period serves as material for the cyclic phase. When loop primers (forward and backwards) are available, they hybridise to the non-cyclic phase end-product and accelerate the rate of the reaction and enhance sensitivity [23]. The large size of LAMP reaction amplicon with loop shape as an end product makes the result visible to the naked eye [49]. Unlike PCR that has only two primers per reaction, with no formation of loop-shaped end-product. The likelihood of seeing it using naked eye is low because of the smaller size amplicon as well low number of the amplified product when compared to LAMP assay [4].

\subsection{LAMP Point-Of-Care Testing (POCT) Ability}

POCT refers to medical diagnostic testing that done near a patient at the time the patient receives medical care [50]. Accuracy, precision and timely diagnosis of human infections and genetic disorders are paramount for effective management of patients and reducing the financial burden, slowing the emergence of drug resistance and lowering morbidity and mortality rates $[51,52]$. The nucleic acid-based technique (NAT) is the gold standard for some gene-based identification of microorganisms. However, such methods like PCR involve multi-analytical steps comprising nucleic acid (DNA/RNA) extraction from the sample, target gene amplification and detection. Such processes require centralised laboratories to carry them out and present hindrance, particularly in resource-limited settings [24]. However, with the advent of the LAMP technique, direct treatment of the sample becomes possible with excellent precision and reproducibility in the field or near the patient in hospital settings [22,51].

\section{COMPARATIVE ADVANTAGES OF LAMP TECHNIQUE OVER OTHER NUCLEIC ACID-BASED DIAGNOSTIC TESTS}

Nucleic acid amplification is an essential tool for virtually all life science research. Many approaches developed, each with specific innovation to re-initiate nucleic acid amplification. Such techniques include cross-priming amplification assay (CPA), rolling circle amplification (RCA), helicase dependent amplification (HDA), strand displacement amplification (SDA), self-sustained sequence replication (3SR), nucleic acid sequencebased amplification (NASBA) [46,57,58], PCR [59] and LAMP [60]. They mainly differ in reaction time, type of nucleic acid amplified (RNA or DNA), the requirement for a precision thermal cycler, dNTP modification, enzyme involvement, reaction temperature, method of amplification and many more [11]. Table 2 depicts the summary of differences and similarities of the significant techniques based on their mechanisms of action and other properties. LAMP POCT approach to diagnosis has many advantages as listed in Table 2. 
Table 1. Comparative accuracy between LAMP and PCR assays for the detection of microbial pathogens

\begin{tabular}{|c|c|c|c|c|c|}
\hline LAMP technique & Target & LAMP specificity & LAMP LoD & PCR LoD & Reference \\
\hline Conventional LAMP & Streptococcus pneumoniae/lytA & $83.9 \%(73 / 88)$ & $10^{1}$ copies/reaction & $10^{4}$ copies/reaction & [23] \\
\hline LAMP-LFD & Vibrio parahaemolyticus/tlh & $100 \%$ & 3 cfu/reaction & 30 cfu/reaction & [53] \\
\hline $\begin{array}{l}\text { Conventional LAMP } \\
\text { (EtBr) }\end{array}$ & Toxoplasma gondii/529 fragment & $17 / 200(8.5 \%)$ & $1 \mathrm{pg} / \mu \mathrm{L}$ & $10 \mathrm{pg} / \mu \mathrm{L}$ & [54] \\
\hline $\begin{array}{l}\text { Conventional LAMP } \\
\text { (gel) }\end{array}$ & $\begin{array}{l}\text { Trichomonas vaginalis/NDMR } \\
100 \text { 18S RNA }\end{array}$ & $\begin{array}{l}53 / 121 \\
(46.06 \%)\end{array}$ & $0.036 \mathrm{ng} / \mu \mathrm{L}$ & $0.36 \mathrm{ng} / \mu \mathrm{L}$ & {$[5]$} \\
\hline $\begin{array}{l}\text { Conventional LAMP } \\
\text { (SYBR green) }\end{array}$ & Coxsackievirus B3/ CVB3 & $100 \%$ & 10 pg/reaction & $100 \mathrm{fg} /$ reaction & [7] \\
\hline $\begin{array}{l}\text { Conventional LAMP } \\
\text { (SYBR green) }\end{array}$ & $\begin{array}{l}\text { Enterohemorrhagic E. coli/rfbe; } \\
\text { shiga toxins stx1and } 2\end{array}$ & $100 \%$ & $10 \mathrm{pg} / \mu \mathrm{L}$ & $10 \mathrm{ng} / \mu \mathrm{L}$ & {$[55]$} \\
\hline $\begin{array}{l}\text { Conventional LAMP } \\
\text { (SYBR green) }\end{array}$ & $\begin{array}{l}\text { Cryptococcus neoformans/C. } \\
\text { gatti/ura5 }\end{array}$ & $\begin{array}{l}5 / 142(3.5 \%) \\
(2 / 107(1.85 \%) \text { CSF; } \\
3 / 35(8.5 \%) \text { serum })\end{array}$ & 5 copies/reaction & 50 copies/reaction & {$[56]$} \\
\hline AuNP - LAMP & $\begin{array}{l}\text { Vibrio parahaemolyticus } \\
\left(V P_{A H P N D}\right) \operatorname{Pir}^{v p} A\end{array}$ & $100 \%$ & $10^{2} \mathrm{cfu} / \mathrm{ml}$ & $10^{4} \mathrm{cfu} / \mathrm{ml}$ & [6] \\
\hline
\end{tabular}

${ }^{a}$ LoD: Limit of detection; ${ }^{b}$ LFD: lateral flow dipstick; ${ }^{d}$ AuNP: nanogold probe; LAMP: loop-mediated isothermal amplification 
Table 2. Comparative analysis of LAMP and other molecular-based diagnostic tests

\begin{tabular}{|c|c|c|c|c|c|c|}
\hline No. & Properties & LAMP & PCR & NASBA & 3SR & SDA \\
\hline 1. & $\begin{array}{l}\text { Naked-eye } \\
\text { detection }\end{array}$ & $\begin{array}{l}\text { Amenable to visual } \\
\text { (naked) detection based } \\
\text { on turbidity }\end{array}$ & $\begin{array}{l}\text { Not responsive to } \\
\text { visual detection }\end{array}$ & $\begin{array}{l}\text { Not sensitive to visual } \\
\text { detection }\end{array}$ & $\begin{array}{l}\text { Not responsive to } \\
\text { visual detection }\end{array}$ & $\begin{array}{l}\text { Not amenable to visual } \\
\text { detection }\end{array}$ \\
\hline 2. & Primers used & Four-six primers & Only two primers & Only two primers & Only two primers & Only one primer \\
\hline 3. & Rapidity & It is rapid, $30-60 \mathrm{~min}$ & $\begin{array}{l}\text { High TAT, }>1 \mathrm{~h} \text { to } \\
\text { amplify }\end{array}$ & $\begin{array}{l}\text { Rapid, } 30 \text { min } \\
\text { reaction time }\end{array}$ & $1-2 h$ & $2 \mathrm{~h}$ \\
\hline 4. & $\begin{array}{l}\text { Type DNA } \\
\text { polymerase } \\
\text { used }\end{array}$ & $\begin{array}{l}\text { Bst polymerase } \\
\text { produced by Bacillus } \\
\text { stearothermophilus }\end{array}$ & $\begin{array}{l}\text { Taq polymerase } \\
\text { provided by Thermus } \\
\text { aquaticus }\end{array}$ & $\begin{array}{l}\text { T7 RNA polymerase } \\
\text { derived from T7 } \\
\text { bacteriophage }\end{array}$ & $\begin{array}{l}\text { AMV-RT; RNase H } \\
\text { and T7 RNA } \\
\text { polymerase }\end{array}$ & $\begin{array}{l}\text { Bst polymerase produced by } \\
\text { Bacillus stearothermophilus }\end{array}$ \\
\hline 5. & $\begin{array}{l}\text { Role(s) of DNA } \\
\text { polymerase } \\
\text { enzyme }\end{array}$ & $\begin{array}{l}\text { Strand displacement and } \\
\text { amplification of the target } \\
\text { gene }\end{array}$ & $\begin{array}{l}\text { Amplification of } \\
\text { target gene }\end{array}$ & $\begin{array}{l}\text { AMV-RT: reverse } \\
\text { transcription } \\
\text { RNase H: RNA sense } \\
\text { strand digestion }\end{array}$ & $\begin{array}{l}\text { AMV-RT: reverse } \\
\text { transcription } \\
\text { RNase H: RNA sense } \\
\text { strand digestion }\end{array}$ & $\begin{array}{l}\text { Two enzymes cut the RE } \\
\text { sites for sequence flanking }\end{array}$ \\
\hline 6. & $\begin{array}{l}\text { Temperature } \\
\text { Used }\end{array}$ & $\begin{array}{l}\text { Requires isothermal } \\
\text { temperature } 60-65^{\circ} \mathrm{C}\end{array}$ & $\begin{array}{l}\text { It involves the use of } \\
\text { alternating } \\
\text { temperatures }\end{array}$ & $\begin{array}{l}\text { Requires isothermal } \\
\text { temperature } 40^{\circ} \mathrm{C}\end{array}$ & $\begin{array}{l}\text { Requires isothermal } \\
\text { temperature } 40^{\circ} \mathrm{C}\end{array}$ & $\begin{array}{l}\text { Requires isothermal } T^{\circ} 37- \\
40^{\circ} \mathrm{C} \text {; still requires } 95^{\circ} \mathrm{C} \text { for } \\
\text { denaturation }\end{array}$ \\
\hline 7. & $\begin{array}{l}\text { Inhibitors } \\
\text { tolerance }\end{array}$ & $\begin{array}{l}\text { Tolerant to sample matrix } \\
\text { inhibitors, e.g. serum, } \\
\text { anticoagulant }\end{array}$ & $\begin{array}{l}\text { Sensitive to sample } \\
\text { matrix inhibitors }\end{array}$ & $\begin{array}{l}\text { Sensitive to sample } \\
\text { matrix inhibitors }\end{array}$ & $\begin{array}{l}\text { Sensitive to sample } \\
\text { matrix inhibitors }\end{array}$ & $\begin{array}{l}\text { Reactions inhibited in the } \\
\text { presence of high human } \\
\text { DNA, glycerol, formamide }\end{array}$ \\
\hline 8. & $\begin{array}{l}\text { Nature of } \\
\text { amplicons }\end{array}$ & $\begin{array}{l}\text { Reaction amplicon: a } \\
\text { mixture of stem-loop } \\
\text { DNAs with various sizes } \\
\text { of the stem and } \\
\text { cauliflower-like structures }\end{array}$ & $\begin{array}{l}\text { No stem-loop and } \\
\text { cauliflower-like } \\
\text { structures formed, } \\
\text { thus increases TAT }\end{array}$ & $\begin{array}{l}\text { No stem-loop and } \\
\text { cauliflower-like } \\
\text { structures built thus } \\
\text { increases TAT }\end{array}$ & $\begin{array}{l}\text { No stem-loop and } \\
\text { cauliflower-like } \\
\text { structures formed thus } \\
\text { increases TAT }\end{array}$ & $\begin{array}{l}\text { No stem-loop and } \\
\text { cauliflower-like structures } \\
\text { formed thus increases TAT }\end{array}$ \\
\hline 9. & $\begin{array}{l}\text { Nucleic-acid } \\
\text { extraction/Direct } \\
\text { sample } \\
\text { preparation }\end{array}$ & $\begin{array}{l}\text { It may/may not require } \\
\text { DNA extraction and } \\
\text { sample preparation. }\end{array}$ & Necessary & Necessary & Necessary & Necessary \\
\hline 10. & $\begin{array}{l}\text { Method of } \\
\text { amplification }\end{array}$ & Strand displacement & Heat denaturation & Reverse transcription & Reverse transcription & $\begin{array}{l}\text { Restriction digestion and } \\
\text { strand displacement }\end{array}$ \\
\hline 11. & $\begin{array}{l}\text { Nucleic acid } \\
\text { detected }\end{array}$ & DNA/RNA to cDNA & DNA/RNA & RNA & RNA & DNA/RNA \\
\hline
\end{tabular}




\section{LIMITATIONS OF LAMP TECHNIQUE}

Though there are many advantages that the LAMP technique has, it also comes with some limitations. One of the striking disadvantages is the possibility of contamination, either by healthy human flora (Staphylococcus aureus, Staphylococcus sapropyticus) or cosmopolitan fungi (e.g. Aspergillus species). It is the reason for LAMP not to be recommended for the detection of such organisms. Also, the final products of LAMP reaction are a composite of multiple concatemer amplicons with different band sizes observed in a characteristic "ladderlike" pattern on a gel. In contrast, the PCR technique has only a single band per template for easy identification of size and analysis [34]. The multiple size amplicons render it to be unsuitable for cloning work, unlike PCR [61]. Nevertheless, these disadvantages do not discount it from not being used as a detection and identification tool for pathogens for molecular diagnostic purposes.

\section{CONCLUSION}

In conclusion, our findings from previous studies showed excellent performance of LAMP over PCR technique. The significant advantages of interest to many researchers are the nonrequirement for thermal cycler machine and simple expertise requirement. The simplicity, rapidity, high specificity, sensitivity and POCT integration, suggest pieces of evidence of acceptance, especially in resource-limited settings. Understanding the technics shows that LAMP is superior over other molecular-based techniques, including conventional PCR. The LAMP is a perfect molecular technique that satisfied the WHO set criteria on an ideal diagnostic tool. Though it has some few limitations, its advantages outweigh its flaws.

\section{COMPETING INTERESTS}

Authors have declared that no competing interests exist.

\section{REFERENCES}

1. Metin, Dilek N, Bilgili GS. Recurrent candidal intertrigo: Challenges and solutions. 2018;175-85.

2. Fidler G, Leiter E, Kocsube S, Biro S, Paholcsek M. Validation of a simplex PCR assay enabling reliable identification of clinically relevant Candida species. BMC Infectious Diseases. 2018;18(1):1-13.
3. Consortium OPATHY and Toni Gabaldon. Recent trends in molecular diagnostics of yeast infections: From PCR to NGS. FEMS Microbiology Reviews. 2019;43(5):51747.

4. Abdullahi UF, Igwenagu E, Jumli MN. Comparative advantage of the novel loopmediated isothermal amplification technique over the conventional polymerase chain reaction. International Journal of Scientific Study. 2015;3(8):1727.

5. Adao DEV, Rivera WL. Original papers Loop-mediated isothermal amplification (LAMP) assay for the rapid detection of the sexually-transmitted parasite, Trichomonas vaginalis. 2016;62(1):25-31.

6. Arunrut N, Kampeera J, Sirithammajak S, Sanguanrut $\mathrm{P}$, Proespraiwong $\mathrm{P}$, Suebsing $R$, et al. Sensitive visual detection of AHPND bacteria using loop-mediated isothermal amplification combined with DNAFunctionalized gold nanoparticles as probes. PLoS ONE. 2016;11(3).

7. Monazah A, Zeinoddini M, Saeeidinia AR. Evaluation of a rapid detection for Coxsackievirus B3 using one-step reverse transcription loop-mediated isothermal amplification (RT-LAMP). Journal of Virological Methods. 2017;246(5):27-33.

8. Li YJ, Fan JY. Rapid visual identification of bovine meat by loop-mediated isothermal amplification combined with the immunochromatographic strip. Biochip Journal. 2017;11(1):8-13.

9. Duncan $R$, Kourout $M$, Grigorenko $E$, Fisher C, Dong M. Advances in multiplex nucleic acid diagnostics for blood-borne pathogens: Promises and pitfalls. Expert Review of Molecular Diagnostics [Internet]. 2016;16(1):83-95.

Available:http://dx.doi.org/10.1586/147371 59.2016.1112272

10. Zhang C, Yao Y, Zhu J-L, Zhang S-N, Zhang S-S, Wei $\mathrm{H}$, et al. Establishment and application of a real-time loopmediated isothermal amplification system for the detection of CYP2C19 polymorphisms. Scientific Reports [Internet]. 2016;6(1):26533.

Available:http://www.nature.com/articles/sr ep26533

11. Notomi $T$, Okayama $H$, Masubuchi $H$, Yonekawa T, Watanabe K, Amino N, et al. Loop-mediated isothermal amplification of DNA. Nucleic acids research [Internet]. 2000;28(12):E63. 
Available:http://www.ncbi.nlm.nih.gov/pub med/10871386\%5Cnhttp://www.pubmedce ntral.nih.gov/articlerender.fcgi?artid=PMC1 02748

12. Zhang $X$, Lowe SB, Gooding JJ. Brief review of monitoring methods for loopmediated isothermal amplification (LAMP). Biosensors and Bioelectronics [Internet]. 2014;61:491-9.

Available:http://dx.doi.org/10.1016/j.bios.20 14.05.039

13. Li Y, Fan P, Zhou S, Zhang L. Loopmediated isothermal amplification (LAMP): A novel rapid detection platform for pathogens. Microbial Pathogenesis [Internet]. 2017;107:54-61.

Available:http://dx.doi.org/10.1016/j.micpat h.2017.03.016

14. Kosack CS, Page A, Klatser PR. A guide to aid the selection of diagnostic tests. 2017;(October 2016):639-45.

15. Wang G, Shang $Y$, Wang $Y$, Tian H, Liu X. Comparison of a loop-mediated isothermal amplification for orf virus with quantitative real-time PCR. Virology Journal. 2013;10: 1-8.

16. Yang B-Y, Liu X-L, Wei Y-M, Wang J-Q, He $X-Q$, Jin $Y$, et al. Rapid and sensitive detection of human astrovirus in water samples by loop-mediated isothermal amplification with hydroxy naphthol blue dye. BMC Microbiology [Internet]. 2014;14(1):38.

Available:http://bmcmicrobiol.biomedcentra I.com/articles/10.1186/1471-2180-14-38

17. Niessen L. Current state and future perspectives of loop-mediated isothermal amplification (LAMP)-based diagnosis of filamentous fungi and yeasts. Applied Microbiology and Biotechnology. 2014;99(2):553-74.

18. Kirunda $\mathrm{H}$, Thekisoe OMM, Kasaija PD, Kerfua SD, Nasinyama GW, Opuda-Asibo $\mathrm{J}$, et al. Use of reverse transcriptase loopmediated isothermal amplification assay for field detection of Newcastle disease virus using less invasive samples. Veterinary World. 2012;5(4):206-12.

19. Li J, Xiong C, Liu Y, Liang J, Zhou X. Loop-Mediated Isothermal Amplification (LAMP): Emergence as an alternative technology for herbal medicine identification. Frontiers in Plant Science [Internet]. 2016;7(December 2016):1-11. Available:http://journal.frontiersin.org/articl e/10.3389/fpls.2016.01956/full
20. Tian B, Ma J, Zardán Gómez De La Torre T, Bálint Á, Donolato M, Hansen MF, et al. Rapid newcastle disease virus detection based on loop-mediated isothermal amplification and optomagnetic readout. ACS Sensors. 2016;1(10):1228-34.

21. Tanner NA, Evans TC. Loop-mediated isothermal amplification for detection of nucleic acids. Current Protocols in Molecular Biology. 2014;1:15.14.115.14.14.

22. Chen C, Liu $P$, Zhao X, Du W, Feng X, Liu BF. A self-contained microfluidic in-gel loop-mediated isothermal amplification for multiplexed pathogen detection. Sensors and Actuators, B: Chemical [Internet]. 2017;239:1-8.

Available:http://dx.doi.org/10.1016/j.snb.20 16.07.164

23. Seki M, Kilgore PE, Kim EJ, Ohnishi M, Hayakawa S, Kim DW. Loop-mediated isothermal amplification methods for the diagnosis of bacterial meningitis. Frontiers in Pediatrics [Internet]. 2018;6(March):1-6. Available:http://journal.frontiersin.org/articl e/10.3389/fped.2018.00057/full

24. Park BH, Oh SJ, Jung JH, Choi G, Seo JH, $\mathrm{Kim} \mathrm{DH}$, et al. An integrated rotary microfluidic system with DNA extraction, loop-mediated isothermal amplification, and lateral flow strip based detection for point-of-care pathogen diagnostics. Biosensors and Bioelectronics [Internet]. 2017;91(December 2016):334-40.

Available:http://dx.doi.org/10.1016/j.bios.20 16.11.063

25. Wang Y, Li H, Li D, Li K, Wang Y, Xu J, et al. Multiple cross displacement amplification combined with gold nanoparticle-based lateral flow biosensor for the detection of Vibrio parahaemolyticus. Frontiers in Microbiology. 2016;7(DEC):1-9.

26. Kubota $R$, Jenkins DM. Real-time duplex applications of loop-mediated amplification (LAMP) by assimilating probes. International Journal of Molecular Sciences. 2015;16(3):4786-99.

27. Kasahara $\mathrm{K}$, Ishikawa $\mathrm{H}$, Sato $\mathrm{S}$, Shimakawa Y, Watanabe K. Development of multiplex loop-mediated isothermal amplification assays to detect medically important yeasts in dairy products. FEMS Microbiology Letters. 2014;357(2):208-16.

28. Mandappa IM, Joglekar P. Loop-Mediated Isothermal Amplification (LAMP) assay for 
rapid detection of Bacillus cereus toxin genes. 2016;5(1):430-42.

29. Abdul-Ghani R, Al-Mekhlafi AM, Karanis P. Loop-mediated isothermal amplification (LAMP) for malarial parasites of humans: Would it come to clinical reality as a pointof-care test? Acta Tropica. 2012;122(3): 233-40.

30. Drancourt M, Michel-Lepage A, Boyer S, Raoult $D$. The point-of-care laboratory in clinical microbiology. Clin Microbiol Rev. 2016;29(3):429-47.

31. Thekisoe OMM, Bazie RSB, CoronelServian AM, Sugimoto C, Kawazu Sichiro, Inoue N. Stability of loop-mediated isothermal amplification (LAMP) reagents and its amplification efficiency on crude trypanosome DNA templates. Journal of Veterinary Medical Science. 2009;71(4): 471-5.

32. Notomi et al. Loop-mediated isothermal amplification (LAMP): Principle, features and future prospects. Journal of Microbiology. 2015;53.

33. Connelly JT, Rolland JP, Whitesides GM. "Paper Machine" for molecular diagnostics. Analytical Chemistry [Internet]. 2015; 87(15):7595-601.

[Cited 2018 Aug 8]

Available:http://pubs.acs.org/doi/10.1021/a cs.analchem.5b00411

34. Sahoo PR, Sethy K, Mohapatra S, Panda D. Loop-mediated isothermal amplification: An innovative gene amplification technique for animal diseases. Veterinary World. 2016;9(5).

35. Combs LG, Warren JE, Huynh V, Castaneda J, Golden TD, Roby RK. The effects of metal ion PCR inhibitors on results obtained with the Quantifiler ${ }^{\circledR}$ Human DNA Quantification Kit. Forensic Science International: Genetics. 2015;19: 180-9.

36. Lee D, Kim YT, Lee JW, Kim DH, Seo TS. An integrated direct loop-mediated isothermal amplification microdevice incorporated with an immunochromatographic strip for bacteria detection in human whole blood and milk without a sample preparation step. Biosensors and Bioelectronics [Internet]. 2016;79:273-9.

Available:http://dx.doi.org/10.1016/j.bios.2 015.12.044

37. Schrader C, Schielke A, Ellerbroek L, Johne R. PCR inhibitors - occurrence, properties and removal. Journal of Applied Microbiology. 2012;113(5):1014-26.

38. Mori $\mathrm{Y}$, Kanda H, Notomi T. Loopmediated isothermal amplification (LAMP): recent progress in research and development. Journal of Infection and Chemotherapy [Internet]. 2013;19(3):40411.

[Cited 2018 Jun 2]

Available:https://www.sciencedirect.com/sc ience/article/pii/S1341321X13701223

39. Kaneko H, Kawana T, Fukushima E, Suzutani T. Tolerance of loop-mediated isothermal amplification to a culture medium and biological substances. Journal of Biochemical and Biophysical Methods. 2007;70(3):499-501.

40. Inácio J, Flores $\mathrm{O}$, Spencer-Martins I. Efficient identification of clinically relevant Candida yeast species by use of an assay combining panfungal loop-mediated isothermal DNA amplification with hybridisation to species-specific oligonucleotide probes. Journal of Clinical Microbiology. 2008;46(2):713-20.

41. Kiddle $G$, Hardinge $P$, Buttigieg $N$, Gandelman O, Pereira C, McElgunn CJ, et al. GMO detection using a bioluminescent real-time reporter (BART) of loop-mediated isothermal amplification (LAMP) suitable for field use. BMC Biotechnology. 2012;12.

42. Sowmya N, Thakur MS, Manonmani HK. Rapid and simple DNA extraction method for the detection of enterotoxigenic Staphylococcus aureus directly from food samples: Comparison of PCR and LAMP methods. Journal of Applied Microbiology. 2012;113(1):106-13.

43. Moradi A, Almasi MA, Jafary $H$, MercadoBlanco J. A novel and rapid loop-mediated isothermal amplification assay for the specific detection of Verticillium dahliae. Journal of Applied Microbiology. 2014;116(4):942-54.

44. Niessen L, Luo J, Denschlag C, Vogel RF. The application of loop-mediated isothermal amplification (LAMP) in food testing for bacterial pathogens and fungal contaminants. Food Microbiology [Internet]. 2013;36(2):191-206.

[Cited 2018 Jun 2]

Available:https://www.sciencedirect.com/sc ience/article/pii/S0740002013000865

45. Wong YP, Othman S, Lau YL, Radu S, Chee HY. Loop-mediated isothermal amplification (LAMP): A versatile technique for the detection of microorganisms. 
Journal of Applied Microbiology. 2018;124(3):626-43.

46. Chang $\mathrm{CC}$, Chen CC, Wei SC, Lu HH, Liang $\mathrm{YH}$, Lin CW. Diagnostic devices for isothermal nucleic acid amplification. Sensors (Switzerland). 2012;12(6):8319_ 37.

47. Oscorbin IP, Belousova EA, Boyarskikh UA, Zakabunin AI, Khrapov EA, Filipenko ML. Derivatives of Bst-like Gss-polymerase with improved processivity and inhibitor tolerance. Nucleic Acids Research. 2017;45(16):9595-610.

48. Ignatov $\mathrm{KB}$, Barsova $\mathrm{EV}$, Fradkov AF, Blagodatskikh KA, Kramarova TV, Kramarov VM. A strong strand displacement activity of thermostable DNA polymerase markedly improves the results of DNA amplification. BioTechniques. 2014;57(2):81-7.

49. Wang Y, Li H, Wang Y, Zhang L, Xu J, Ye C. Loop-mediated isothermal amplification label-based gold nanoparticles lateral flow biosensor for detection of Enterococcus faecalis and Staphylococcus aureus. Frontiers in Microbiology. 2017;8(Feb).

50. Tang $\mathrm{R}$, Yang $\mathrm{H}$, Gong $\mathrm{Y}$, Liu Z, Li XJ, Wen $T$, et al. Improved analytical sensitivity of lateral flow assay using sponge for HBV nucleic acid detection. Scientific Reports [Internet]. 2017;7(1):110.

Available:http://dx.doi.org/10.1038/s41598017-01558-x

51. Cordeiro M, Carlos FF, Pedrosa P, Lopez A, Baptista PV. Gold nanoparticles for diagnostics: Advances towards Points of care. 2016;1.

52. Wu Z, Fu Q, Yu S, Sheng L, Xu M, Yao C, et al.Pt@AuNPs integrated quantitative capillary-based biosensors for point-ofcare testing application. Biosensors and Bioelectronics. 2016;85:657-63.

53. Prompamorn $P, \quad$ Sithigorngul $P$, Rukpratanporn S, Longyant S, Sridulyakul $P$, Chaivisuthangkura $P$. The development of loop-mediated isothermal amplification combined with lateral flow dipstick for detection of Vibrio parahaemolyticus.
Letters in Applied Microbiology. 2011;52(4):344-51.

54. Abdoli A, Dalimi A, Soltanghoraee $H$, Ghaffarifar $F$. Molecular detection of Toxoplasma gondii in the house sparrow (Passer domesticus) by LAMP and PCR methods in Tehran, Iran. Journal of Parasitic Diseases [Internet]. 2016;40(4): 1317-21.

Available:http://dx.doi.org/10.1007/s12639015-0680-2

55. Yan M, Xu L, Jiang $H$, Zhou Z, Zhou S, Zhang L. PMA-LAMP for rapid detection of Escherichia coli and shiga toxins from the viable but non-culturable state. Microbial Pathogenesis [Internet]. 2017;105:245-50. Available:http://dx.doi.org/10.1016/j.micpat h.2017.02.001

56. Alireza Rezaei Amirabadi. LOOP mediated isothermal AMPlification (LAMP) in the diagnosis of neorocryptococcosis. African Journal of Biotechnology. 2012;11(17): 3986-92.

57. Mueller JD, Pütz B, Höfler H. Selfsustained sequence replication (3SR): An alternative to PCR. Histochemistry and Cell Biology. 1997;108(4-5):431-7.

58. Wang DG, Brewster JD, Paul M, Tomasula PM. Two methods for increased specificity and sensitivity in loop-mediated isothermal amplification. Molecules. 2015;20(4):604859.

59. Dale JW, Schantz MVON, Plant N. From Genes. 2012;402.

60. Hansen ZR, Knaus BJ, Tabima JF, Press $\mathrm{CM}$, Judelson $\mathrm{HS}$, Grünwald $\mathrm{NJ}$, et al. Loop-mediated isothermal amplification for detection of the tomato and potato late blight pathogen, Phytophthora infestans. Journal of Applied Microbiology. 2016;120(4):1010-20.

61. Rekha V, Rana R, Remesh Arun $T$, Bharathan Aswathi P, Kalluvila John J, Gopinath D, et al. LAMP-A novel nucleic acid-based diagnostic assay. Advances in Animal and Veterinary Sciences Online [Internet]. 2014;2(6):344-50.

Available:http://dx.doi.org/10.14737/journal .aavs/2014/2.6.344.350

(C) 2020 Hassan and Than; This is an Open Access article distributed under the terms of the Creative Commons Attribution License (http://creativecommons.org/licenses/by/4.0), which permits unrestricted use, distribution, and reproduction in any medium, provided the original work is properly cited.

Peer-review history:

The peer review history for this paper can be accessed here: http://www.sdiarticle4.com/review-history/59713 